\title{
CD1d expression and invariant natural killer T-cell numbers are reduced in patients with upper gastrointestinal cancers and are further impaired by commonly used chemotherapies
}

\author{
Ashanty M. Melo ${ }^{1,2} \cdot$ Melissa J. Conroy ${ }^{2} \cdot$ Emma K. Foley $^{2} \cdot$ Éilis Dockry $^{1} \cdot$ Eamon P. Breen $^{3} \cdot$ John V. Reynolds $^{2}$. \\ Joanne Lysaght ${ }^{2} \cdot$ Derek G. Doherty $^{1}$ (i)
}

Received: 8 April 2019 / Accepted: 2 February 2020 / Published online: 20 February 2020

(c) Springer-Verlag GmbH Germany, part of Springer Nature 2020

\begin{abstract}
Esophageal and gastric cancers collectively cause over 1.1 million deaths annually and only $20-30 \%$ of patients respond favorably to current therapies. Cellular therapies using invariant natural killer T (iNKT) cells are showing promise for patients with other cancers; therefore, we investigated if these cells are altered in esophageal and gastric cancer patients. Flow cytometric analysis of peripheral blood from 139 patients revealed that iNKT cells are depleted from patients with esophageal and gastric adenocarcinoma and esophageal squamous cell carcinoma, both before and after treatment. Interrogation of the KMPlot database of transcriptomic data from 876 gastric cancer patients revealed that low CD1d expression is associated with poor prognosis. These observations suggest that therapies that boost CD1d expression and iNKT cell responses may benefit these patients. However, we found that chemotherapies used for esophageal and gastric cancers have adverse effects on iNKT cells in vitro. Cisplatin caused a significant reduction of CD1d expression by esophageal tumor cell lines. Cisplatin, 5-fluorouracil and carboplatin induced dose-dependent apoptosis in primary lines of iNKT cells and inhibited CD1d-dependent interferon- $\gamma$ production and cytolytic degranulation by viable iNKT cells. Interestingly, cisplatin increased granzyme B and perforin production and decreased the production of the granzyme B inhibitor PI9, which protects cytotoxic cells from self-damage by granzyme B. Thus, cisplatin-induced apoptosis of iNKT cells may be mediated in part by altering granzyme B and PI9 expression. Our data suggest that iNKT cell-based immunotherapies may benefit patients with gastrointestinal cancers, but may be negatively affected by chemotherapies used for these cancers.
\end{abstract}

Keywords Esophageal cancer $\cdot$ Gastric cancer $\cdot$ iNKT cells $\cdot$ CD1d $\cdot$ Chemotherapy $\cdot$ Immunotherapy

$\begin{array}{ll}\text { Abbreviations } \\ \text { 7-AAD } & \text { 7-Aminoactinomycin } \\ \text { BMI } & \text { Body mass index } \\ \text { EAC } & \text { Esophageal adenocarcinoma } \\ \text { EC } & \text { Esophageal cancer }\end{array}$

Joanne Lysaght and Derek G. Doherty contributed equally to the direction of this study.

Derek G. Doherty

derek.doherty@tcd.ie

1 Department of Immunology, Trinity Translational Medicine Institute, Trinity College Dublin, St. James's Hospital, Dublin 8, Ireland

2 Department of Surgery, Trinity Translational Medicine Institute, Trinity College Dublin, Dublin, Ireland

3 Flow Cytometry Facility, Trinity Translational Medicine Institute, Trinity College Dublin, Dublin, Ireland

$\begin{array}{ll}\text { GAC } & \text { Gastric cancer } \\ \alpha \text {-GalCer } & \alpha \text {-Galactosylceramide } \\ \text { iNKT } & \text { Invariant natural killer T cells } \\ \text { PI } & \text { Propidium iodide } \\ \text { TRG } & \text { Tumor regression grading }\end{array}$

\section{Introduction}

Gastric cancer (GAC) is the sixth most common cancer worldwide, with over 1 million new cases and almost 0.8 million deaths in 2018 [1]. Esophageal cancer (EC) is the ninth most common cancer worldwide, with over 0.5 million new cases and deaths in 2018 [1]. EC has two major subtypes: esophageal adenocarcinoma (EAC) and squamous cell carcinoma (SCC). EAC accounts for $\sim 12 \%$ of cases of EC globally, while SCC accounts for $~ 88 \%$. On the contrary, in Western countries, EAC has become more prevalent than 
SCC, reflecting the rise in obesity, gastro-esophageal reflux disease and Barrett's esophagus [2,3]. Treatment for upper gastrointestinal cancers normally involves a combination of surgery, chemotherapy and radiotherapy. The most common chemotherapy drugs used to treat EC and GAC are cisplatin, 5-fluoruoracil (5-FU), carboplatin and paclitaxel [4]. Only $30 \%$ of EC patients and $25 \%$ of GAC patients respond to treatment leading to dismal 5-year survival rates of $15-25 \%$ of EC patients and $25-35 \%$ of GAC patients [4, 5]. Clearly, new treatments for EC and GAC are required.

Invariant natural killer T (iNKT) cells are a subset of cytotoxic $\mathrm{T}$ cells with potent antitumor activities. They are characterized by the expression of semi-invariant T-cell receptors (TCR), which recognize glycolipid antigens presented by the major histocompatibility complex (MHC) class I-like molecule CD1d [6, 7]. iNKT cells recognise a number of self and microbial glycolipids, but most studies have used the xenogeneic glycolipid $\alpha$-galactosylceramide $(\alpha-$ GalCer) $[6,7]$. iNKT cells can also be activated by ligation of cytokine receptors and an array of stimulatory, costimulatory and inhibitory receptors found on natural killer (NK) cells. Upon activation, iNKT cells kill target cells by secreting granzyme $\mathrm{B}$ and perforin, which induce apoptosis of tumor cells by caspase-dependent pathways [8]. iNKT cell activation also results in the rapid secretion of a diverse array of $\mathrm{T}$ cell-polarizing cytokines, leading to activation and regulation of other immune cells including NK cells, dendritic cells (DC), macrophages, neutrophils, T cells and B cells. The cytokine profiles of iNKT cells define multiple functional subsets, which include tumor-promoting as well as tumor-killing effectors [6,7].

Cellular immunotherapies involving the ex vivo expansion and activation of autologous immune cells and infusion back into patients are showing promise for cancer treatment. So far, clinical trials have used $\alpha$-GalCer, $\alpha$-GalCer-pulsed autologous DC, or autologous iNKT cells expanded ex vivo using $\alpha$-GalCer or anti-CD3 antibody in the presence of IL-2 [9-13]. However, in all studies, the clinical efficacies were modest. It is possible that the iNKT cell-based immunotherapies in humans demonstrated poor efficacy because of advanced disease, or because their cellular immune responses are impaired by previous or ongoing use of conventional cytotoxic chemotherapies or radiotherapies. In the present study, we have evaluated the utility of iNKT cellbased immunotherapies for gastrointestinal cancers if used in combination with first-line chemotherapies by assessing how cisplatin, 5-FU, paclitaxel and carboplatin affect iNKT cell functions. This study provides new insights into the potential use of NKT cell-based immunotherapies for GAC, EAC and SCC at a time when immunotherapies are revolutionizing cancer treatment.

\section{Materials and methods}

\section{Subjects}

Whole blood samples were obtained from 139 patients with EAC, SCC or GAC (114 male; mean age 66) undergoing surgery at St. James's Hospital, Dublin, Ireland. Pretreatment blood was taken at diagnosis and post treatment blood was taken on the day of surgery, which was typically 3 months after diagnosis and 6-8 weeks after cessation of treatment. The demographics of the patients are shown in Table 1. Blood samples were also obtained from 17 healthy donors (10 male; mean age 63).

\section{Antibodies and flow cytometry}

Fluorochrome-conjugated monoclonal antibodies (mAb) specific for human CD3, V $224 \mathrm{~J} \alpha 18$ TCR (clone 6B11), perforin, granzyme $\mathrm{B}, \mathrm{CD} 19, \mathrm{CD} 14, \mathrm{CD} 1 \mathrm{~d}$, (BioLegend) CD45, CD107a, (BD Bioscience), IFN- $\gamma$, IL-4 (Miltenyi Biotec), PI9 (Invitrogen) and the dyes annexin V (Santa Cruz Biotechnologies and BD Bioscience), propidium iodide (PI; Invitrogen) and carboxyfluorescein succinimidyl ester (CFSE; Thermo Fisher) were used. $100 \mu \mathrm{l}$ of whole blood or $0.1-0.5 \times 10^{6}$ of expanded iNKT cells or OE33 cells (EAC cells) was stained with mAbs for $15 \mathrm{~min}$. Red blood cells (in whole blood samples) were lysed with BD lysis buffer. Cells were acquired on a FACSCanto II flow cytometer (BD

Table 1 Demographic information on the patients

\begin{tabular}{llll}
\hline Cancer type & OAC $(n=80)$ & SCC $(n=28)$ & GAC $(n=31)$ \\
\hline Age (years) & $64.5(43-96)$ & $64.2(46-80)$ & $68.4(49-87)$ \\
Sex & $91.3 \%$ male & $64.3 \%$ male & $74.2 \%$ male \\
Treatment $^{\mathrm{a}}$ & & & \\
Chemotherapy & 34 patients & 7 patients & 18 patients \\
Chemoradiation & 21 patients & 13 patients & - \\
Other & 25 patients & 8 patients & 13 patients \\
Tumor regression & & & \\
grading (TRG) & & & \\
1 & 3 & 5 & 1 \\
2 & 3 & 1 & 4 \\
3 & 15 & 2 & 5 \\
4 & 9 & 1 & 4 \\
5 & 6 & 1 & $27.7 \pm 3.9$ \\
Mean body mass & $26.9 \pm 4.6$ & $24.6 \pm 4.1$ & \\
index (BMI) at & & & \\
diagnosis & & & \\
\hline
\end{tabular}

${ }^{\mathrm{a}}$ Other, surgery alone or palliative treatment

${ }^{\mathrm{b}}$ TRG, tumor regression grading. TRG for 40 patients was not available

${ }^{\mathrm{c}} \mathrm{BMI}$, body mass index. BMI for 27 patients was not available 
Bioscience) and analysed using FlowJo Version 10 (Tree Star) software.

\section{Analysis of associations between CD1d mRNA expression and overall survival of gastric cancer patients}

To determine if CD1d mRNA expression in cancer samples is associated with patient survival, we interrogated the KMPlot database of gastric cancer patient groups [14]. In this database, multiple independent transcriptomic datasets, generated using Affymetrix Human Genome Arrays, are merged and can be interrogated to compare outcomes associated with expression levels of mRNA coding for prognostic biomarker candidates. 876 gastric cancer patients were divided into high- and low-CD1d mRNA expression groups, with the best performing threshold being used as the final cut-off in a univariate Cox regression analysis. Basic univariate analysis was performed to assess overall survival in gastric cancer patients of all stages.

\section{Chemotherapy drugs}

The commonly used chemotherapy drugs for upper gastrointestinal cancer, cisplatin, 5-FU, carboplatin and paclitaxel were purchased from Sigma-Aldrich. Stocks were made following the manufacturer's instructions. Cisplatin was reconstituted in $0.15 \mathrm{M}$ sodium chloride to a stock concentration of $3.3 \mathrm{mM}$. 5-FU was reconstituted in dimethylsulfoxide (DMSO) at $100 \mathrm{mM}$. Paclitaxel was reconstituted in DMSO at $10 \mathrm{mM}$. Carboplatin was resuspended in distilled water at $100 \mathrm{mM}$.

\section{Analysis of CD1d expression}

Peripheral blood mononuclear cells (PBMC) were isolated by density gradient centrifugation over Lymphoprep (Stemcell Technologies). Cells were treated with medium alone and various concentrations of cisplatin, 5-FU, carboplatin and paclitaxel. CD1d expression by $\mathrm{B}$ cells $\left(\mathrm{CD} 19^{+} \mathrm{CD}^{-}\right.$cells $)$, monocytes $\left(\mathrm{CD} 14^{+}\right.$cells $)$and the EAC cell line OE33 was analysed by flow cytometry.

\section{Generation of iNKT cell lines}

Primary lines of iNKT cells were generated as described previously [15]. Briefly, PBMC were prepared from buffy coat packs provided by the Irish Blood Transfusion Service. iNKT cells were enriched by magnetic bead separation using anti-iNKT Microbeads (Miltenyi Biotec), followed by labelling with mAbs specific for CD3 and the V $\alpha 24 \mathrm{~J} \alpha 18 \mathrm{TCR}$ and sorting the $\mathrm{CD}^{+}{ }^{+} \mathrm{V} \alpha 24 \mathrm{~J} \alpha 18^{+}$cells using a MoFlo ${ }^{\mathrm{TM}} \mathrm{XDP}$ Cell Sorter (Beckman Coulter). Since iNKT cells generally account for $<0.1 \%$ of PBMC, the magnetic bead pre-enrichment step was necessary to obtain sufficient iNKT cell frequencies for sorting. Sorted iNKT cells were expanded by culturing 1,000 cells in iNKT cell medium [15] and stimulation with $\alpha$-GalCer $(100 \mathrm{ng} / \mathrm{ml})$. Cells were incubated in the presence of $25 \mathrm{~Gy}$ irradiated allogeneic feeder PBMC prepared from two donors. Medium was replaced with fresh iNKT cell medium containing $250 \mathrm{U} / \mathrm{ml} \mathrm{IL-2}$ (Miltenyi Biotec) after $24 \mathrm{~h}$. Cells were expanded for a minimum of 2 weeks before use. The purities of iNKT cells were $>98 \%$ as determined by flow cytometry.

\section{MTT cell viability assay}

iNKT cell viability was measured by the 3-(4,5-dimethylthiazol-2-yl)-2,5-diphenyltetrazolium bromide (MTT) assay. Cells were cultured in serum-depleted medium $(0.5 \%$ FCS $)$ overnight. Cells were treated with different concentrations of chemotherapy drugs for 24 and $48 \mathrm{~h}$. MTT (Sigma-Aldrich) was added to each well for 3-4 h until purple formazan crystals were taken up by the cells. Crystals were dissolved with DMSO and absorbance was read at $595 \mathrm{~nm}$ on a VersaMax microplate reader (Molecular Devices) and analysed using SoftMax Pro software.

\section{Cell death analysis}

Toxicity of chemotherapy drugs against cultured iNKT cells and OE33 cells was tested by flow cytometry using the apoptotic marker annexin $\mathrm{V}$ and marker of necrosis propidium iodide (PI). Cells were cultured overnight in serum-depleted medium. Cells were treated with different concentrations of the drugs. Cells were washed with binding buffer $(10 \mathrm{mM}$ HEPES, $150 \mathrm{mM} \mathrm{NaCl}, 2.5 \mathrm{mM} \mathrm{CaCl}_{2}$, pH 7.4), stained with annexin $\mathrm{V}$ antibody and washed with binding buffer. Immediately before flow cytometry acquisition, PI was added.

\section{CD1d-dependent activation of iNKT cells}

Expanded iNKT cells were stimulated in vitro for $4 \mathrm{~h}$ using mock-transfected or CD1d-transfected HeLa cells or C1R cells (denoted HeLa-mock, HeLa-CD1d, C1R-mock and C1R-CD1d cells) pulsed with $\alpha-$ GalCer [16]. HeLa and C1R cells were cultured in complete DMEM and RPMI media, respectively [16].

HeLa-mock or HeLa-CD1d cells were cultured in 96-well flat bottom microtitre plates and pulsed with $100 \mathrm{ng} / \mathrm{mL} \alpha$-GalCer. After $18 \mathrm{~h}$, the medium was replaced with iNKT cell medium containing equal numbers of iNKT cells and anti-CD107a mAb. $1 \times$ monensin (Biolegend) was added after $1 \mathrm{~h}$ to prevent re-internalization of CD107a. Following $3 \mathrm{~h}$ incubation, cells were stained 
with a Fixable Viability Dye followed by mAbs specific for CD3 and $V \alpha 24 J \alpha 18$ and analysed by flow cytometry.

\section{Measurement of intracellular cytokine, perforin and granzyme B production}

$0.1 \times 10^{6}$ iNKT cells were stimulated for $4 \mathrm{~h}$ with CD1dtransfected HeLa cells, previously pulsed with $100 \mathrm{ng} / \mathrm{mL}$ $\alpha$-GalCer, in the presence of monensin to prevent cytokine release from the cells. Cells were then stained with Fixable Viability Dye, followed by mAb specific for cell surface CD3 and $V \alpha 24 J \alpha 18$. Cells were then fixed with $4 \%$ paraformaldehyde, permeabilized with $0.2 \%$ saponin and stained with antibodies specific for IFN- $\gamma$ and IL-4, or granzyme B and perforin and analysed by flow cytometry.

\section{Total cytotoxicity and apoptosis detection}

iNKT cell cytotoxicity was tested by Total Cytotoxicity and Apoptosis Detection Kit purchased from Immunochemistry Technologies and analysis by flow cytometry. C1R-CD1d or C1R-mock target cells were pulsed with $\alpha$-GalCer, as described above, stained with CFSE and cultured with three different ratios of iNKT cells (1X, 10X, $25 \mathrm{X}$ ) for $5 \mathrm{~h}$ at $37^{\circ} \mathrm{C}$. Cells were stained with annexin $\mathrm{V}$ to identify apoptotic cells and 7-aminoactinomycin D (7-AAD) to detect dead cells and analysed by flow cytometry. Cells treated with $4 \mu \mathrm{g} / \mathrm{ml}$ camptothecin for $5 \mathrm{~h}$ served as apoptosis-positive control, whereas cells treated at $56{ }^{\circ} \mathrm{C}$ for $6 \mathrm{~min}$ were necrosis-positive controls. Target cells were identified with CFSE. Percentage of specific lysis was calculated using the formula:

$$
\begin{aligned}
& \% \text { specific lysis } \\
& \quad=\frac{\%(\mathrm{dead}) \text { target cells }-\% \text { spontaneous }(\mathrm{dead}) \text { target cells }}{100-\% \text { spontaneous }(\text { dead }) \text { targetcells }} \times 100 \% .
\end{aligned}
$$

\section{Immunofluorescence analysis}

Immunofluorescence analysis of granzyme B was performed by blocking non-specific binding of antibodies to iNKT cells using BSA, labelling them with anti-CD45 $\mathrm{mAb}$, fixing them with $4 \%$ paraformaldehyde, permeabilizing them with $0.2 \%$ saponin and staining with an anti-granzyme B mAb. iNKT cells were attached to polyL-lysine-coated slides (Sigma-Aldrich) using a Cytospin. ProLong TM Gold Antifade Mountant with DAPI (Thermo Fisher Scientific) was added, and the slides were left to cure overnight. Images were taken with Lionheart FX Automated Microscope, at 10X magnification and fluorescence intensity was measured using ImageJ software.

\section{Statistical analysis}

Statistical analysis was performed using GraphPad Prism Version 6.0. $p$ values between groups were obtained using the unpaired Mann-Whitney $U$ test or paired $t$ test. $p$ values of $<0.05(*), p<0.01\left(^{* *}\right)$ and $p<0.001(* * *)$ were considered statistically significant.

\section{Results}

\section{Circulating iNKT cell frequencies are diminished in patients with upper gastrointestinal cancers, compared to healthy controls}

The frequencies of iNKT cells, as percentages of total T cells, in peripheral blood from 139 patients with EAC, SCC or GAC were analysed by staining whole blood samples with mAbs specific for CD3, CD45 and V $\alpha 24 \mathrm{~J} \alpha 18$ and analysis by flow cytometry (Fig. 1a). The median frequencies of iNKT cells were significantly lower in blood samples from patients with EAC, SCC and GAC compared to healthy controls ( $p<0.01,0.05$ and 0.05 , respectively; Fig. 1b). No significant differences were observed in the proportions of iNKT cells between patients with EAC, SCC or GAC. The median frequencies of iNKT cells were found to be similar in pre-treatment and post-treatment blood of patients with EAC, SCC and GAC (Fig. 1c). When the patients were stratified according to treatment, no significant differences in iNKT cell frequencies were observed after chemotherapy or chemoradiation treatment (data not shown). iNKT cell frequencies did not correlate with tumor regression grade, determined pathologically by the extent of residual tumor post treatment, and were similar in male and female patients (data not shown).

\section{Higher intratumoral CD1d expression correlates with improved survival in gastric cancer}

CD1d mRNA expression in tumors from datasets on 876 gastric cancer patients was analysed using the KMPlot database [14]. Univariate analysis of mRNA expression determined that high expression of CD1d (found in 650 patients) is associated with significantly improved overall survival compared with those who had low levels of CD1d mRNA expression $(n=226 ; p=0.021$, Fig. 2a). However, after 120 days, the overall survival of patients in the two groups is similar, thus precluding the use of CD1d expression as a prognostic biomarker. No information on CD1d expression was available for esophageal cancer. 
A

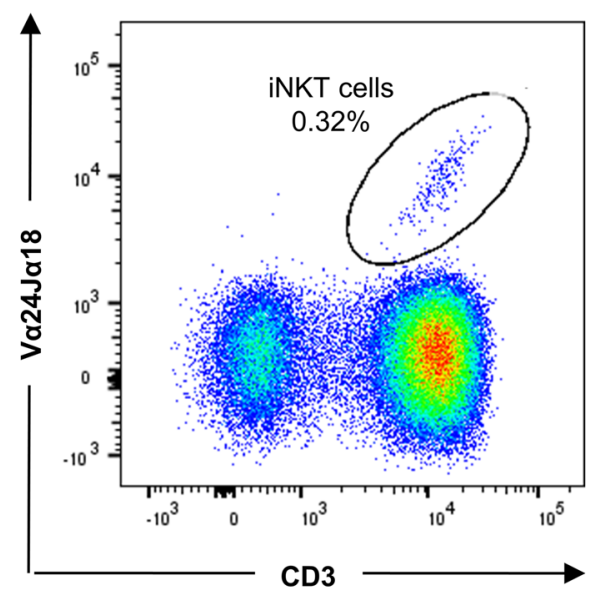

B

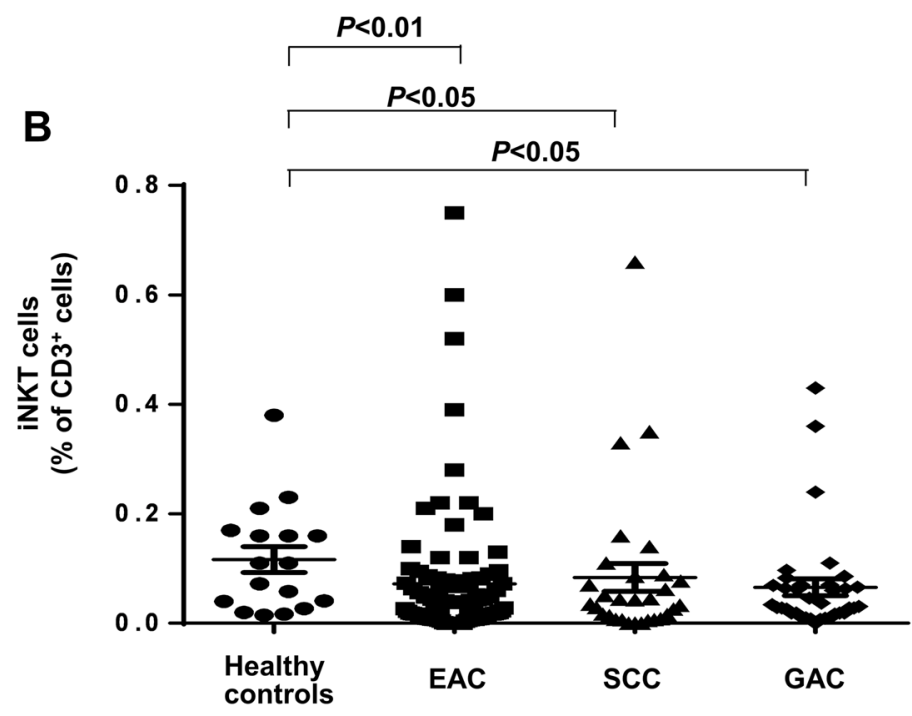

C

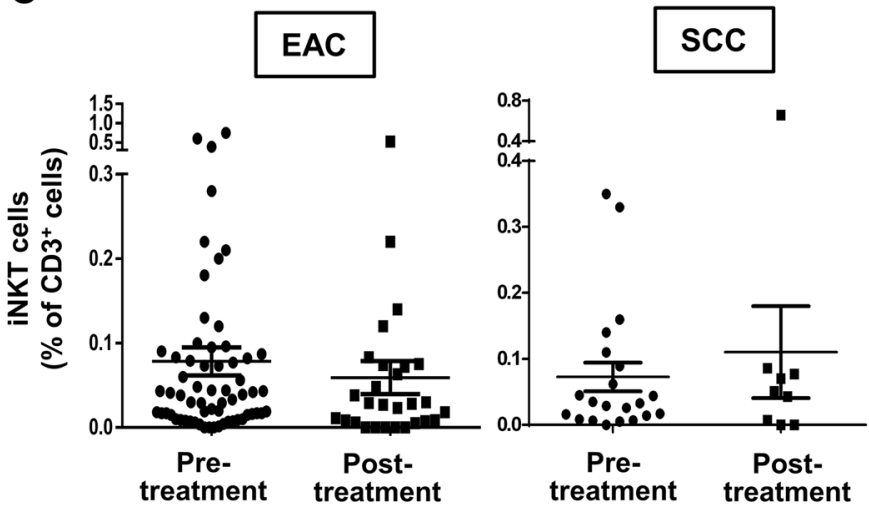

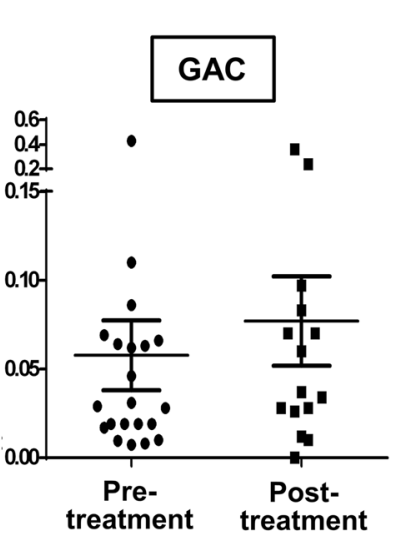

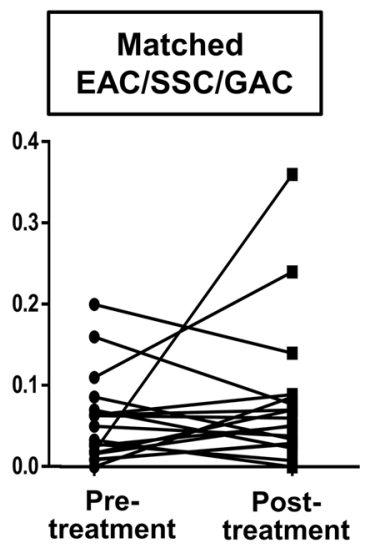

Fig. 1 Frequencies of iNKT cells in peripheral blood from patients with OAC, SCC and GAC. Whole blood from healthy controls and patients with EAC, SCC and GAC was stained with mAb specific for the V $\alpha 24 \mathrm{~J} \alpha 18$ TCR, CD3 and CD45. a Representative flow cytometry dot plot showing CD3 and V $\alpha 24 \mathrm{~J} \alpha 18$ TCR expression by circulating $\mathrm{CD} 45^{+}$cells from a patient with EAC. b Scatterplot showing mean $( \pm$ SEM $)$ frequencies of iNKT cells, as percentages of T cells, from healthy donors $(n=17)$ and patients with EAC $(n=80)$, SCC

\section{Cisplatin treatment reduces cell-surface CD1d expression by esophageal cancer cells}

We next assessed the effect of chemotherapy treatment on CD1d expression by B cells and monocytes within PBMC from five healthy donors, and esophageal cancer cells (OE33 cells). Treatment with cisplatin resulted in a dose-dependent downregulation of CD1d in OE33 cells (Fig. 2b). No significant differences were observed in the mean fluorescence intensity (MFI) of CD1d in treated B cells (Fig. 2c) or monocytes (Fig. 2d) compared to untreated control samples. No significant differences were observed in CD1d expression $(n=28)$ and GAC $(n=31)$. c Scatterplots showing circulating iNKT cell frequencies in pre-treatment and post-treatment patients with EAC $(n=39,24)$, SCC $(\mathrm{n}=21,9)$ and GAC $(n=21,15)$. The righthand panel shows iNKT frequencies in pre-treatment and post-treatment blood from matched patients with EAC $(n=11), \operatorname{SCC}(n=2)$ and GAC $(n=5)$. iNKT cell frequencies in different groups are compared using the Mann-Whitney $U$ test)

in OE33 cells, B cells and monocytes after treatment with 5-FU, carboplatin or paclitaxel (data not shown).

\section{Chemotherapies induce apoptosis in human iNKT cells in vitro}

We next determined the effects of the drugs used for the treatment of upper gastrointestinal cancer on iNKT cell survival. iNKT cell lines were sorted from human blood and expanded in the presence of $\alpha$-GalCer, IL- 2 and irradiated feeders. Expanded iNKT cell lines or OE33 cells were cultured in the absence or presence of cisplatin, 5-FU, carboplatin or paclitaxel for 24 or $48 \mathrm{~h}$ and cell viability was 

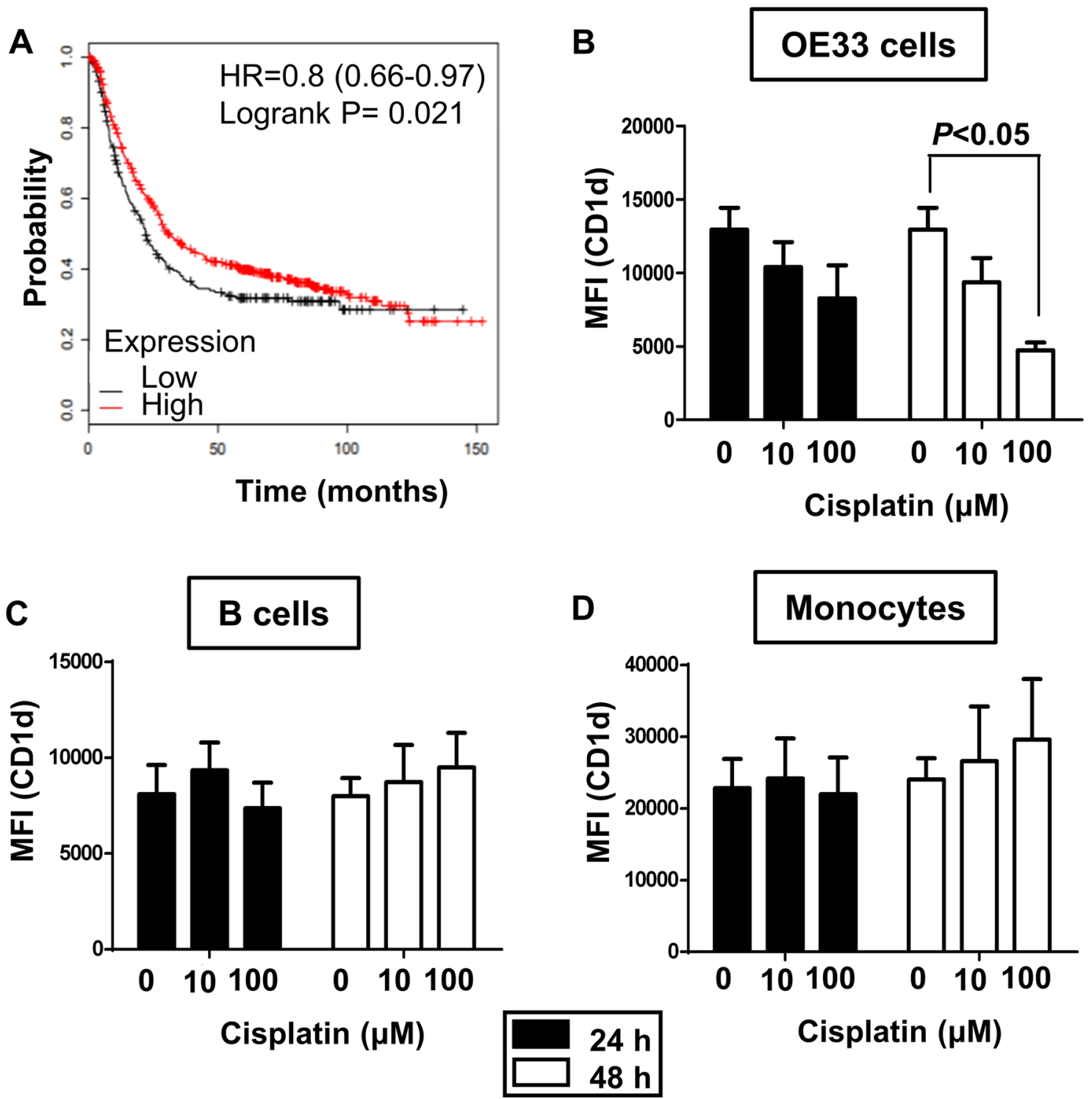

Fig. 2 High expression of CD1d in gastric cancer is associated with improved overall survival but CD1d expression by OAC cells is decreased by cisplatin treatment. a Kaplan-Meier plot analysis of CD1d mRNA expression in 876 patients with gastric cancer demonstrating that high expression of CD1d mRNA is associated with significantly better overall survival $(p=0.021)$. HR, hazard ratio. These data were generated using KMPlot. b-d The effect of cisplatin on CD1d expression by OE33 OAC cells, B cells and monocytes from

five healthy donors. PBMCs or OE33 cells were treated with 0,10 and $100 \mu \mathrm{M}$ cisplatin for 24 and $48 \mathrm{~h}$. Cells were stained for mAbs specific for CD1d, CD19, CD3 and CD14. CD1d expression was analysed by flow cytometry. Graphs show mean $( \pm$ SEM) MFI of CD1d after 24 or $48 \mathrm{~h}$ treatment with cisplatin on OE33 cells (b), B cells $\left(\mathrm{CD} 19^{+} \mathrm{CD}^{-}\right.$; $\mathbf{c}$ and monocytes $\left(\mathrm{CD} 14^{+} ; \mathbf{d}\right) . \mathrm{CD} 1 \mathrm{~d}$ expression by treated and untreated samples were compared using the paired $t$ test

measured by the MTT assay to obtain the $\mathrm{IC}_{50}$ of the drugs. The $\mathrm{IC}_{50}$ of cisplatin for iNKT cells was $42.6 \mu \mathrm{M}$, for 5-FU was $243.3 \mu \mathrm{M}$, for carboplatin was $62.1 \mu \mathrm{M}$ and for paclitaxel was $54.7 \mu \mathrm{M}$. We did not measure the $\mathrm{IC}_{50}$ of the drugs for conventional $\mathrm{T}$ cells, so these results may not be specific to iNKT cells, but may be a general T-cell effect. Toxicity was also examined by staining the cells for annexin $\mathrm{V}$ and PI and analysis by flow cytometry (Fig. 3a). Apoptosis of iNKT cells was observed after $24 \mathrm{~h}$ and $48 \mathrm{~h}$ treatment with cisplatin (Fig. 3b). 5-FU (Fig. 3c), carboplatin (Fig. 3d) and paclitaxel (Fig. 3e) did not significantly increase iNKT apoptosis after $24 \mathrm{~h}$, but $100 \mu \mathrm{M}$ 5-FU and $10 \mu \mathrm{M}$ carboplatin caused significant apoptosis of iNKT cells after $48 \mathrm{~h}$. Significant increases in OE33 cell death was observed with the four drugs at $24 \mathrm{~h}$ and $48 \mathrm{~h}$. 
Fig. 3 Chemotherapies induce apoptosis in human iNKT cells in vitro. Lines of expanded iNKT cells or OE33 cells were cultured for 24 or $48 \mathrm{~h}$ with medium alone or $0-100 \mu \mathrm{M}$ of cisplatin, $0-100 \mu \mathrm{M} 5-\mathrm{FU}$, $0-50 \mu \mathrm{M}$ carboplatin or $0-50 \mu \mathrm{M}$ paclitaxel. iNKT cells and OE33 cells were then stained with Annexin V and PI and analysed by flow cytometry (a). Graphs show mean $( \pm$ SEM) percentages of apoptotic iNKT cells (left panels: $n=5$ ) or OE33 cells (right panels; $n=5$ ) after 24 or $48 \mathrm{~h}$ treatment with cisplatin (b), 5-FU (c), carboplatin (d) and paclitaxel (e). $(* p<0.05$, $* * p<0.01, * * * p<0.001$, $* * * * p<0.0001$ using the paired $t$ test compared to untreated)
A

iNKT cells

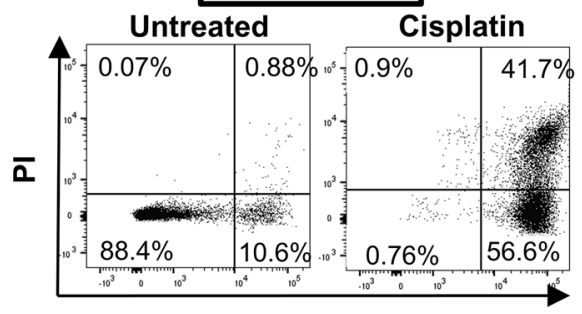

Annexin V

B

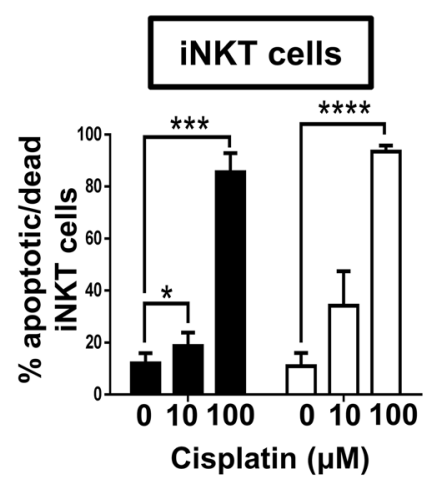

C

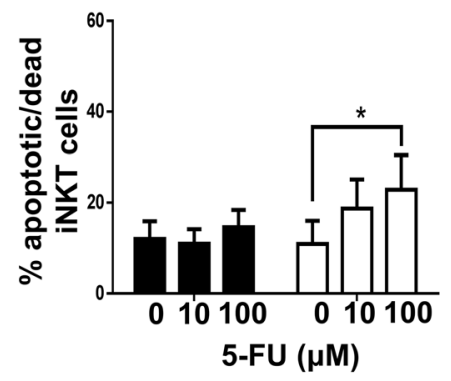

D

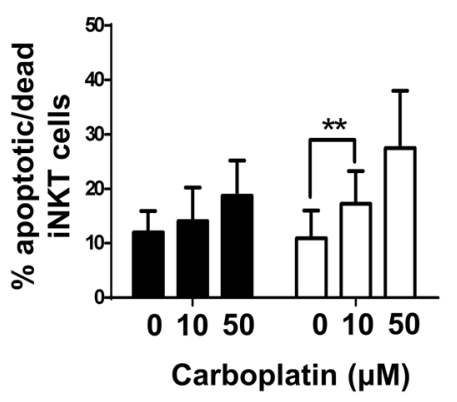

E

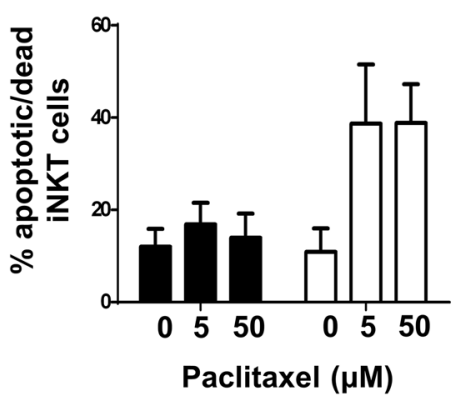

\section{OE33 cells}

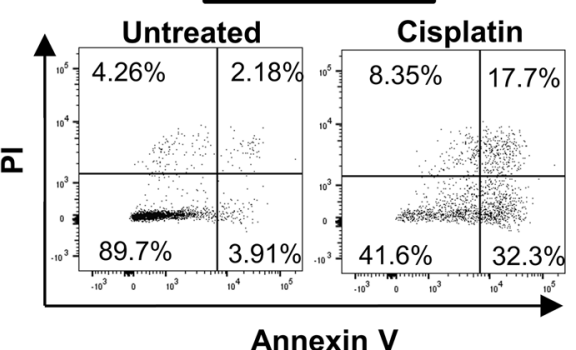

Annexin V
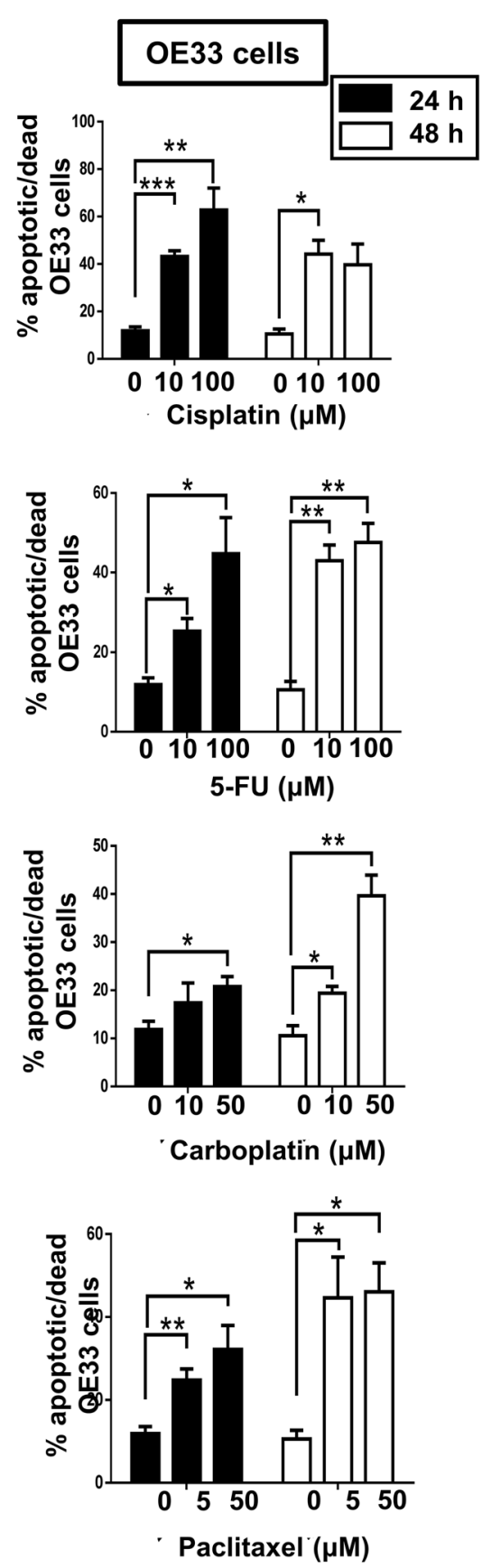

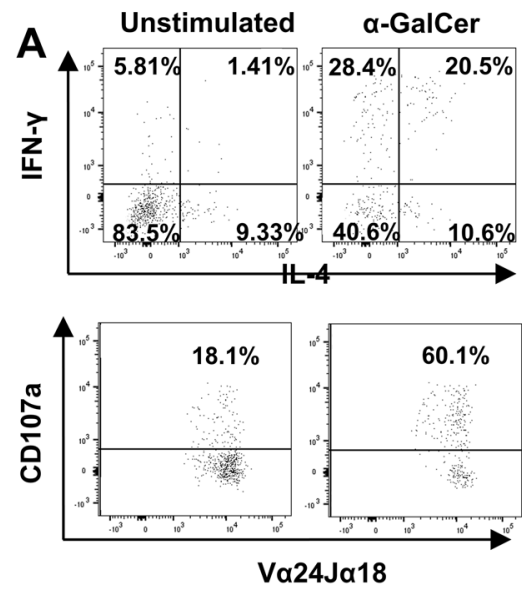

B

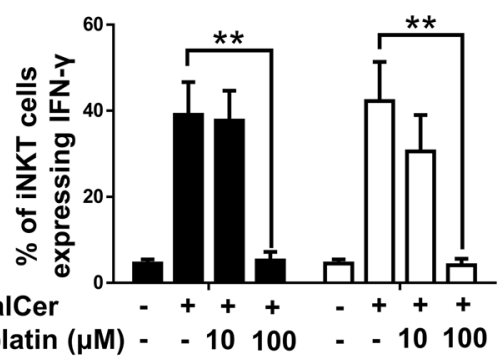

C

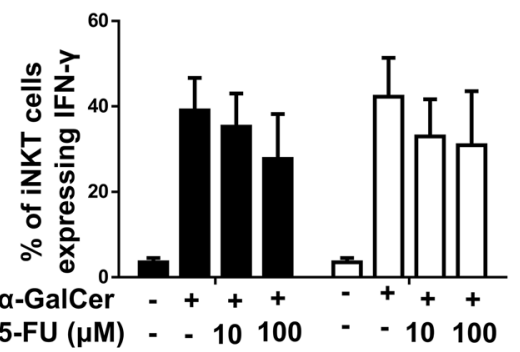

D

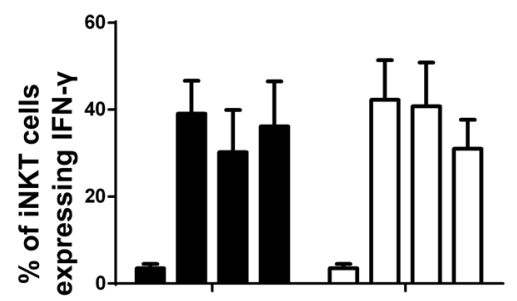

a-GalCer

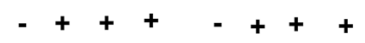

Carboplatin $(\mu \mathrm{M})-\quad-1050 \quad-1050$

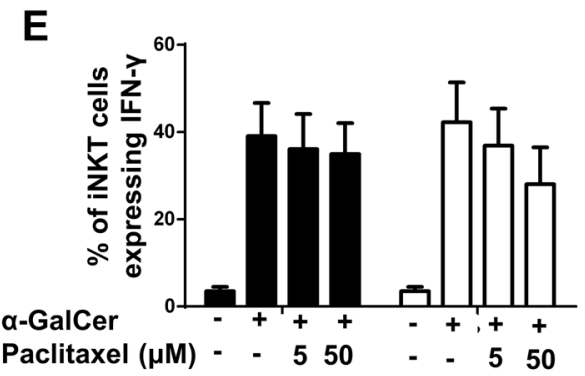

$\mathbf{F}$

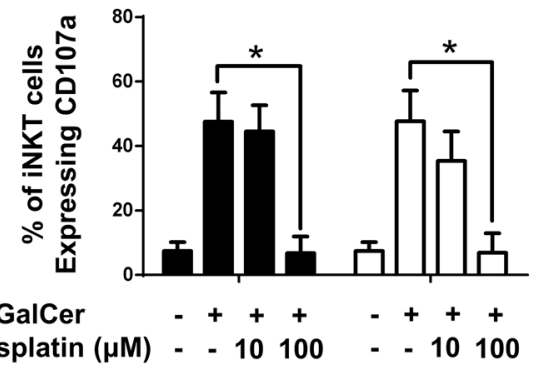

G

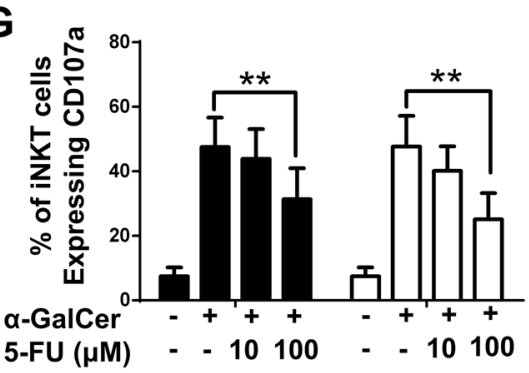

H

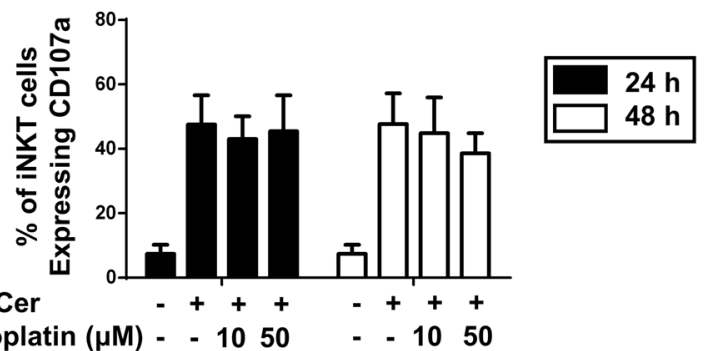

I

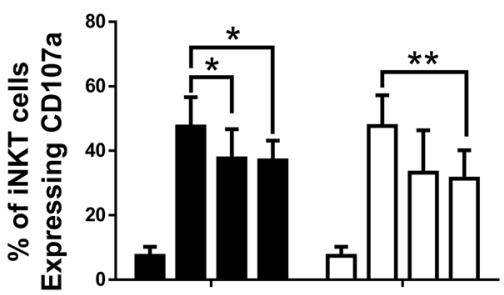

a-GalCer

$-++-+++$

Paclitaxel $(\mu \mathrm{M})$ - -550 - 550

J

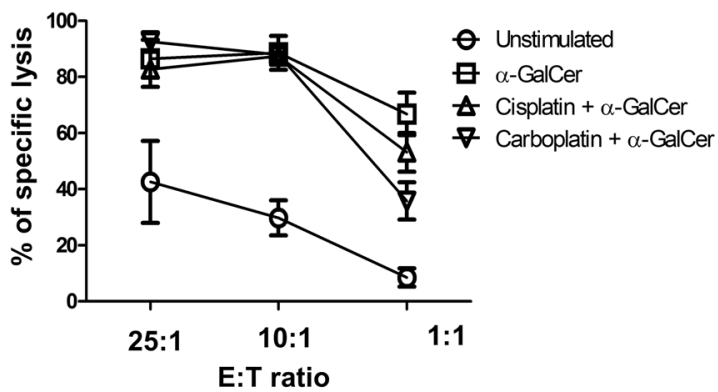


४Fig. 4 Cisplatin, 5-FU, paclitaxel but not carboplatin inhibit cytolytic degranulation, whereas cisplatin only inhibits IFN- $\gamma$ production by viable iNKT cells in vitro. Lines of expanded iNKT cells were cultured for 24 or $48 \mathrm{~h}$ with medium alone or cisplatin, 5-FU, carboplatin or paclitaxel. Cells were then co-cultured for $4 \mathrm{~h}$ with CD1dtransfected HeLa cells, previously pulsed with $\alpha$-GalCer. Cells were then stained with mAbs specific for cell-surface CD3, CD45 and V $\alpha 24 \mathrm{~J} \alpha 18$, intracellular IFN- $\gamma$ and IL-4, and CD107a and analysed by flow cytometry $(\mathbf{a})$. b-i Graphs show mean $( \pm$ SEM) percentages of viable iNKT cells that produced IFN- $\gamma$ and CD107a after 24 and $48 \mathrm{~h}$ treatment with cisplatin $(\mathbf{b}, \mathbf{f}), 5$-FU $(\mathbf{c}, \mathbf{g})$, carboplatin $(\mathbf{d}, \mathbf{h})$ and paclitaxel $(\mathbf{e}, \mathbf{i})$. To test direct killing by iNKT cells after treatment, iNKT cells were treated for $48 \mathrm{~h}$ with medium, $10 \mu \mathrm{M}$ cisplatin or $50 \mu \mathrm{M}$ carboplatin and then co-cultured for $5 \mathrm{~h}$ with CD1d-transfected C1R target cells, previously pulsed with $\alpha$-GalCer. Target cells were stained with CFSE, apoptotic cells were positive for Annexin V and dead cells for 7-AAD by flow cytometry. Graph showing mean $( \pm$ SEM) percentages of specific lysis of CD1d-transfected C1Rs by iNKT cells $(\mathbf{j})$. Results are means of 5 independent experiments $\left(* p<0.05,{ }^{*} p<0.01\right.$, using the paired $t$ test compared to stimulated with $\alpha$-GalCer)

\section{Chemotherapies significantly reduce IFN- $\gamma$ production and cytolytic degranulation by viable iNKT cells}

The above experiments indicate that cisplatin, 5-FU, carboplatin and paclitaxel induce apoptosis in a proportion of iNKT cells. We next investigated if these drugs affected the functions of the remaining viable iNKT cells. Lines of iNKT cells were treated with medium alone, cisplatin (10 or $100 \mu \mathrm{M}), 5-\mathrm{FU}(10$ or $100 \mu \mathrm{M})$, carboplatin $(10$ or $50 \mu \mathrm{M})$ or paclitaxel $(5$ or $50 \mu \mathrm{M})$ for 24 and $48 \mathrm{~h}$. These concentrations span the range of plasma concentrations of the drugs found in patients, measured in a number of publications, which vary according to dose and time after administration. The cells were then co-cultured for $4 \mathrm{~h}$ with CD1d-transfected HeLa cells or C1R cells that were previously pulsed with $100 \mathrm{ng} / \mathrm{mL} \alpha$-GalCer. The proportions of viable iNKT cells producing intracellular IFN- $\gamma$, IL-4 and expressing cellsurface CD107a were quantified by flow cytometry (Fig. 4a). CD1d-transfected HeLa cells pulsed with $\alpha$-GalCer induced significant IFN- $\gamma$ expression by iNKT cells. After 24 and $48 \mathrm{~h}$ treatment with $100 \mu \mathrm{M}$ cisplatin, we observed a significant inhibition of IFN- $\gamma$ expression by stimulated viable iNKT cells (Fig. 4b). No significant decrease in IFN- $\gamma$ expression by viable iNKT cells was observed following 5-FU (Fig. 4c), carboplatin (Fig. 4d) or paclitaxel (Fig. 4e) treatment when compared with untreated iNKT cells. IL-4 was not altered after treatment (data not shown). The ability of cisplatin to inhibit IFN- $\gamma$ production by iNKT cells could be an unwanted side effect of this drug.

iNKT cells upregulated the cytolytic degranulation marker CD107a after stimulation with $\alpha$-GalCer (Fig. 4f). Expression of CD107a by viable iNKT cells was reduced to unstimulated levels after treatment with $100 \mu \mathrm{M}$ cisplatin
(Fig. 4f). $100 \mu \mathrm{M}$ 5-FU (Fig. 4g) and paclitaxel (Fig. 4i) significantly reduced CD107a expression by viable iNKT cells after $24 \mathrm{~h}(5$ and $50 \mu \mathrm{M})$ and $48 \mathrm{~h}(50 \mu \mathrm{M})$. Treatment with carboplatin did not alter CD107a expression (Fig. 4h).

To check that cytolytic degranulation, as evidenced by CD107a induction, is associated with target cell death, we also examined direct killing of C1R-CD1d cells by iNKT cells after treatment with the platinum analogues cisplatin and carboplatin. $\alpha$-GalCer primed C1R-CD1d cells for killing by iNKT cells at E:T ratios of 25:1, 10:1 and 1:1. Addition of $10 \mu \mathrm{M}$ of cisplatin or $50 \mu \mathrm{M}$ carboplatin did not significantly affect the percentages of target cells that were specifically lysed when compared to the untreated control (Fig. $4 \mathrm{j}$ ), suggesting that cytotoxic function of the cells is still intact.

\section{Granzyme B and perforin production by iNKT cells is increased following cisplatin, but not 5-FU, carboplatin or paclitaxel treatment}

Expanded iNKT cell lines were treated with medium alone, cisplatin $(10$ or $100 \mu \mathrm{M})$, 5-FU (10 or $100 \mu \mathrm{M})$, carboplatin $(10$ or $50 \mu \mathrm{M})$, or paclitaxel $(5$ or $50 \mu \mathrm{M})$ for 24 or $48 \mathrm{~h}$, and co-cultured for $4 \mathrm{~h}$ with equal numbers of CD1d-transfected HeLa cells, previously loaded with medium alone or $100 \mathrm{ng} /$ $\mathrm{mL} \alpha$-GalCer. The proportions of iNKT cells producing granzyme B (Fig. 5a) and perforin (Fig. 5b) were quantified by flow cytometry. Up to $40 \%$ of iNKT cells produced granzyme $\mathrm{B}$ and $35 \%$ expressed perforin in the presence of CD1d-transfected HeLa cells pulsed with $\alpha$-GalCer. Following treatment with $100 \mu \mathrm{M}$ cisplatin, viable iNKT cells exhibited a significant increase of granzyme B (Fig. 5c) and perforin (Fig. 5d) when stimulated with $\alpha$-GalCer pulsed CD1d-transfected HeLa cells. This was confirmed for granzyme B by immunofluorescence analysis. Granzyme B fluorescence intensity in iNKT cells increased after $24 \mathrm{~h}$ treatment with $100 \mu \mathrm{M}$ cisplatin $(p=0.0569$ when compared with $\alpha$-GalCer stimulation, Fig. 5f). No significant difference in granzyme B or perforin production by activated iNKT cells was observed when treated with 5-FU, carboplatin and paclitaxel (data not shown). We then investigated if cisplatin treatment results in a reduction in the expression of PI9 (also known as serpin 9), an intracellular serine protease inhibitor that protects NK and iNKT cells from self-damage by granzyme B [17] (Fig. 5g). While $10 \mu \mathrm{M}$ cisplatin did not affect PI-9 expression by iNKT cells, $100 \mu \mathrm{M}$ cisplatin significantly reduced the frequency (Fig. 5h) and intensity (Fig. 5I) of PI-9 expression. Interrogation of the KMPlotter database of 876 patients with gastric cancer [14] indicated that low PI-9 gene expression is also with poor survival $(p=0.02)$. Upregulation of perforin and granzyme B and downregulation of PI-9 by cisplatin, leading to granzyme 
A

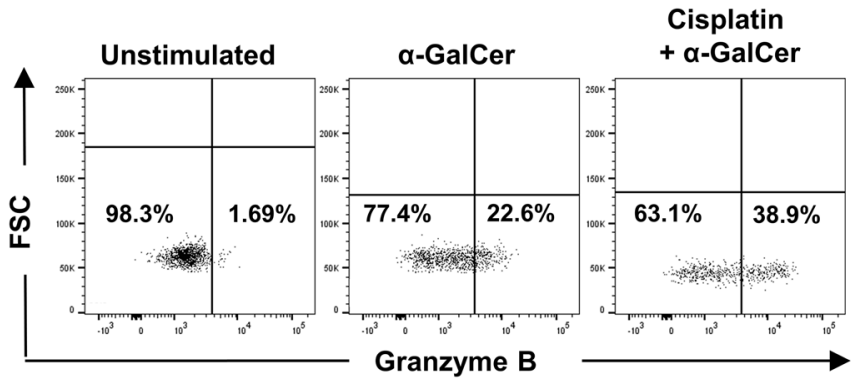

B

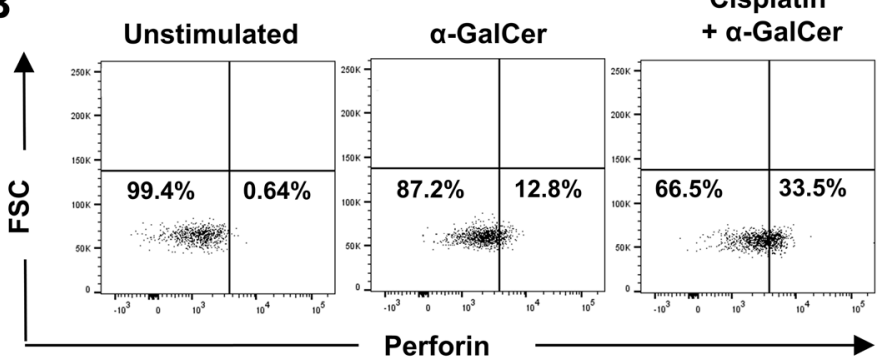

E
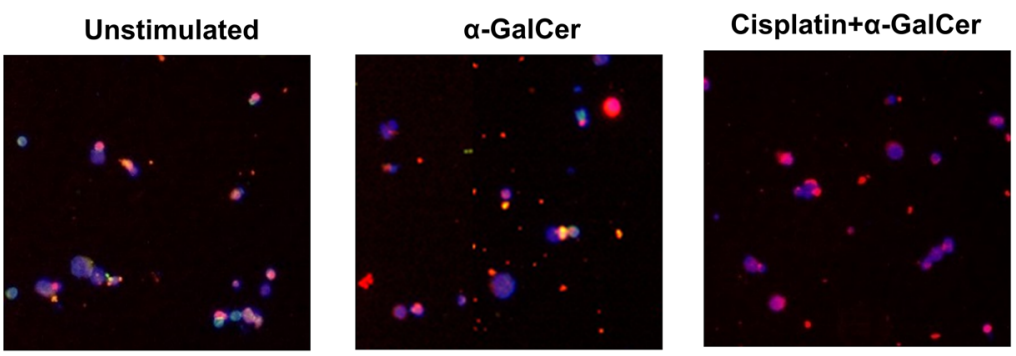

C

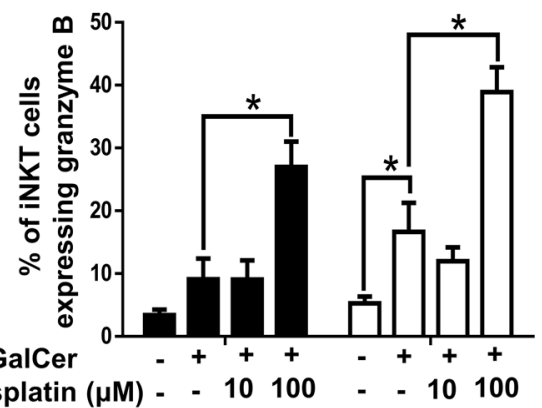

$24 \mathrm{~h}$

D

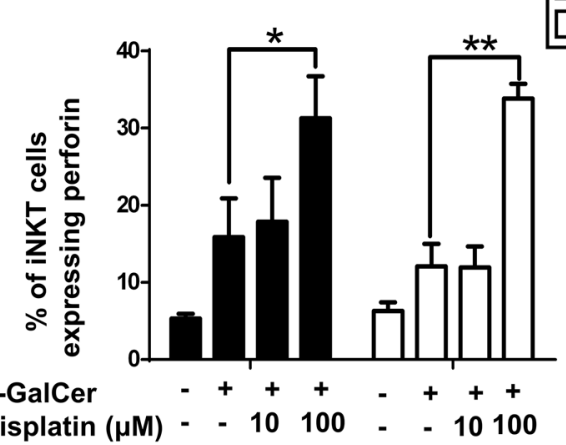

G

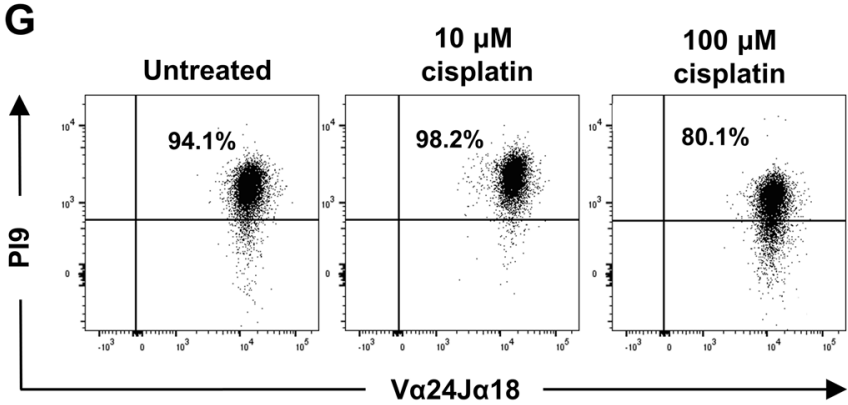

Fig. 5 Cisplatin increases granzyme B and perforin production by viable iNKT cells in vitro. Lines of expanded iNKT cells were cultured for 24 or $48 \mathrm{~h}$ with medium alone or $0-100 \mu \mathrm{M}$ cisplatin, 5-FU, $0-50 \mu \mathrm{M}$ carboplatin or $0-50 \mu \mathrm{M}$ paclitaxel. Cells were co-cultured with CD1dtransfected HeLa cells, previously pulsed with $\alpha$-GalCer. Cells were then stained with $\mathrm{mAb}$ specific for granzyme $\mathrm{B}$, perforin, $\mathrm{CD} 3, \mathrm{CD} 45$ and 6B11 and analysed by flow cytometry $(\mathbf{a}, \mathbf{b})$. Graphs showing mean $( \pm$ SEM) percentages of viable iNKT cells from 5 donors producing granzyme B (c), perforin (d) after 24 or $48 \mathrm{~h}$ treatment with cisplatin. Cells were treated for $24 \mathrm{~h}$ and stained for immunofluorescence
H

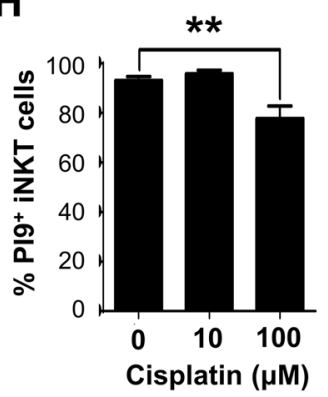

I

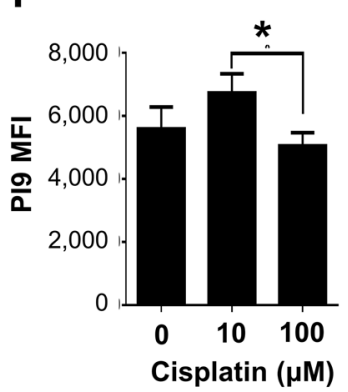

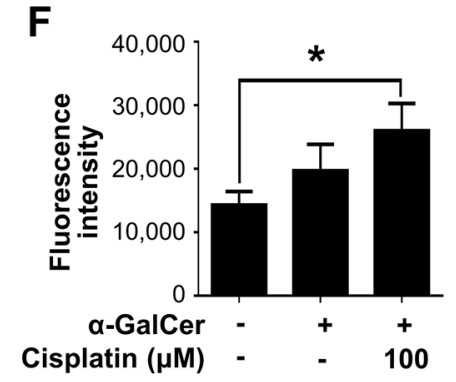

microscopy. Representative immunofluorescence images, blue: nuclei, green: CD45, red: granzyme B (e). Graph showing fluorescence intensity of granzyme B on iNKT cells after $24 \mathrm{~h}$ treatment with cisplatin (f). iNKT cell lines were treated with two doses of cisplatin and stained for PI9, and analysed by flow cytometry (g). h Graphs showing mean $( \pm$ SEM) percentages of viable iNKT cells expressing PI9 $(n=5)$. $\mathbf{i}$ Graph showing mean $( \pm$ SEM) MFI of PI9 after treatment with cisplatin (i). $\left({ }^{*} p<0.05, * * p<0.01\right.$, using the paired $t$ test) 
B-mediated apoptosis of iNKT cells, may be a mechanism by which cisplatin kills iNKT cells.

\section{Discussion}

CD1d-restricted iNKT cells promote anti-tumor immunity in mice and humans by directly killing tumor cells and by contact-dependent and/or cytokine-mediated interactions with other cells of the immune system [6, 7]. However, iNKT cells are depleted and/or functionally impaired in patients with many different malignancies, including rectal, breast, renal, prostate and lung cancers, malignant melanoma and chronic lymphocytic leukaemia [15, 18-21]. Furthermore, some tumor cells including breast [22], cervical [23], lung [15] and chronic lymphocytic leukemia cells [21] can evade immunosurveillance by iNKT cells by downregulating their expression of CD1d. Several clinical trials in cancer patients are attempting to boost iNKT cell numbers and their anti-tumor activities. Therapeutic strategies including intravenous injections of $\alpha$-GalCer, administration of autologous dendritic cells pulsed with $\alpha$-GalCer, and/or transfer of ex vivo expanded and activated iNKT cells, have shown enhanced anti-tumor activity at the tumor site and at sites of metastasis but only moderate disease stabilisation or reduction in tumor mass [9-13]. Additionally, treatments that induce CD1d expression by tumor cells are being tested in vitro $[15,21]$. While cellular therapies involving iNKT cells show great promise for cancer patients, further optimisation is required to achieve clinical benefits.

In the present study, we investigated if iNKT cells and/or CD1d expression are deficient in patients with upper gastrointestinal cancers. By enumerating iNKT cells in peripheral blood from 139 patients using flow cytometry, we found that circulating iNKT cell frequencies were significantly lower in patients with EAC, SSC and GAC compared to age- and sex-matched healthy control subjects. Since tumor tissue from these patients was not available for our study, we interrogated the KMPlot database from transcriptomic datasets on 876 GAC patients and found that low CD1d expression is associated with significantly lower overall survival. Therefore, it is likely that patients with upper gastrointestinal cancers exhibit depletions of iNKT cells as well as downregulated CD1d expression on tumor cells, which would allow them to avoid killing by iNKT cells. Cellular expression of CD1d is likely to be influenced by the intracellular repertoire of glycolipid ligands which may change in response to tumor transformation.

Our observation that iNKT cells are depleted from the circulation of OAC, SSC and GAC patients suggests that iNKT cell-based immunotherapies may benefit these patients. A question remains as to why clinical trials involving iNKT cells have not shown the efficacies seen in mice. While inherent differences between murine and human iNKT cells exist, including numbers, tissue distribution, antigens recognised and functions $[16,18,20]$, we hypothesised that the failure of human clinical trials involving iNKT cells may be because iNKT cell function is being compromised by the chemotherapeutic regimens administrated to patients. The most common chemotherapy drugs used for EC and GAC are cisplatin, 5-FU, carboplatin and paclitaxel [4]. Cisplatin and carboplatin are platinum analogues that bind to purine bases in the DNA, interfering with DNA repair mechanisms, causing cell apoptosis [24]. 5-FU interferes with the synthesis of DNA by inhibiting thymidylate synthase [25]. Paclitaxel causes the polymerization and further stabilization of microtubules, leading to a cell cycle arrest in G2/M phase, inhibiting normal mitosis of the cells [26]. It is likely that the toxic effects that these drugs have on tumor cells will also have negative effects on iNKT cells.

Several studies have shown that cisplatin, 5-FU and paclitaxel can increase MHC class I expression on mouse and human tumor cells [27, 28]. However, their effects on the expression of CD1d are still largely unknown. We tested the effect of chemotherapy drugs on CD1d expression on immune and tumor cells. No effect was observed on CD1d expression on $\mathrm{B}$ cells or monocytes; however, cisplatin caused a dose-dependent downregulation of CD1d on the OAC cell line OE33. Therefore, it is possible that cisplatin causes the downregulation of CD1d on esophageal tumor cells in vivo. Future studies are required to determine if this drug will similarly affect primary esophageal tumor cells or other tumor cells and to ascertain if the use of cisplatin as first line chemotherapy would compromise the efficacy of iNKT based immunotherapies.

Conflicting results have been reported about the effect of chemotherapies on the anti-tumor effector cells of immune system. While some report that 5-FU impairs NK cell functions, others have shown higher numbers of infiltrating cytotoxic T cells and NK cells with enhanced cytotoxicity in breast cancer patients $[29,30]$. Other studies showed that paclitaxel inhibits human NK cell-mediated killing without affecting its viability, but NK cells are not affected by carboplatin and 5-FU [31]. Cisplatin has been shown to enhance the ability of NK cells to suppress hepatocellular carcinoma [32], lung cancer [33] and uterine endometrial cancer [34], and enhances $\mathrm{T}$ cells in a murine model of melanoma [35]. Fallarini et al. [36] found that iNKT cell treatment enhanced cisplatin-induced osteosacoma cell death in a dose-dependent manner.

We describe here, a direct effect of chemotherapy on iNKT cell viability and function. While treatment of OAC, SSC and GAC with these chemotherapies did not lead to significant changes in circulating iNKT cell numbers in vivo, we observed a significant induction of apoptosis of expanded iNKT cells in a dose-dependent manner in 
the presence of cisplatin, 5-FU and carboplatin in vitro. Furthermore, examination of the remaining viable cells indicated that treatment with cisplatin, but not the other drugs, inhibited IFN- $\gamma$ production in response to stimulation with glycolipid presented by CD1d. We saw no inhibition of IL-4 production by cisplatin, suggesting that this drug may lower the ratios of Th1/Th2 cytokines produced by iNKT cells, which might result in the inhibition of the antitumor response.

iNKT cells can directly kill a number of tumor cells in vitro and in vivo via the targeted release of the apoptosisinducing mediators granzyme $\mathrm{B}$ and perforin [6-8]. Conventional chemotherapies have been reported to increase sensitivity to granzyme B and perforin-mediated cell death [37]. We report here that cisplatin, 5-FU and paclitaxel inhibited $\alpha$-GalCer-induced externalization to the iNKT cell surface of the lysosomal marker CD107a, suggesting that these drugs block cytolytic degranulation by iNKT cells. However, cisplatin had no effect on the ability of iNKT cells to kill $\alpha$-GalCer-pulsed HeLa-CD1d cells. Interestingly, using fluorescence microscopy and flow cytometry, we observed an increase in granzyme B and perforin production in response to cisplatin treatment in vitro. We also found that high doses of cisplatin caused a reduction of PI9 expression by iNKT cells and a complete absence of this inhibitor in a subset of iNKT cells. PI9 is a serine protease inhibitor that protects iNKT cells from self-damage by granzyme B [17]. This suggests that the apoptosis of iNKT cells, seen in response to cisplatin treatment, is due in part to their inability to protect themselves from self-damage by granzyme B. Future studies are required to determine if the upregulation of granzyme B and downregulation of PI9 occurs in the same cells, which would add further support for this mechanism of action of cisplatin. The absence of PI9 is associated with poor outcomes in patients with NK/T-cell lymphoma [38]. We find here using the KMPlotter database of 876 gastric cancer patients that low PI-9 gene expression is also with poor survival $(p=0.02)$.

In conclusion, we have shown that iNKT cell numbers are lower in the circulation of patients with EAC, SCC and GAC compared to matched healthy donors and CD1d expression is reduced in patients who have poorer survival rates. These observations suggest that iNKT cells do indeed play a role in immunosurveillance for upper gastrointestinal cancers and that immunotherapies involving iNKT cells may benefit patients. Circulating iNKT cell numbers did not change in response to treatment with cisplatin, 5-FU, carboplatin or paclitaxel; however, exposure of iNKT cells to these drugs in vitro can negatively affect iNKT cell viability and the functional outcomes of stimulating these cells with $\alpha$-GalCer, the ligand used to stimulate iNKT cells in most clinical trials. Thus, the effects of current or previous chemotherapeutic treatment for EAC, SSC and GAC should be considered when developing iNKT cell-based immunotherapies.

Acknowledgements The authors would like to thank the patients and control subjects who were enrolled in this study; the Irish Blood Transfusion Service for kindly providing buffy coat packs; Steven A. Porcelli for providing the CD1d transfectant cell lines; Ana MorenoOlivera, Alhanouf al-Harbi, Nawal Taher and Andreas Solomos for helpful discussions.

Author contributions Ashanty M. Melo, Derek G. Doherty and Joanne Lysaght conceived the study and prepared the manuscript. Ashanty M. Melo, Melissa J. Conroy, Emma K. Foley, Éilis Dockry and Eamon P. Breen performed the laboratory experiments. Ashanty M. Melo analysed the data. John V. Reynolds managed the cancer patients.

Funding This work was supported by grants from the Consejo Nacional de Ciencia y Tecnología (CONACyT, Mexico; to Ashanty Melo), the Irish Health Research Board (to Melissa J. Conroy) and Molecular Medicine Ireland (to Éilis Dockry).

\section{Compliance with ethical standards}

Conflict of interest The authors declare that they have no potential conflicts of interest.

Ethical approval and ethical standards Ethical approval for this study was granted from the St James's and Tallaght Hospitals Research Ethics Committee (Approval no. 2011/27/01; July 27, 2011) and the Trinity College Dublin School of Medicine Research Ethics Committee (Approval no. 20170908; September 27, 2017). The study was carried out in accordance with the Declaration of Helsinki ethical guidelines for medical research involving human subjects.

Informed consent All specimens were collected with prior informed written consent of patients and healthy donors to obtain, store and use their blood samples for phenotypic and functional studies on immune cells, and to use their clinical data and the results of these studies for research and publication. Ethical approval was obtained for the use without consent, of used buffy coat packs, obtained from the Irish Blood Transfusion Service, because these specimens were fully anonymized.

Cell line authentication Mock-transfected and CD1d-transfected HeLa and C1R cells were a kind gift from Prof. Steven A. Porcelli, Albert Einstein College of Medicine, New York. Their identities and expression of transfected CD1d were validated by flow cytometry.

\section{References}

1. Bray F, Ferlay J, Soerjomataram I, Siegel RL, Torre LA, Jemal A (2018) Global cancer statistics 2018: GLOBOCAN estimates of incidence and mortality worldwide for 36 cancers in 185 countries. CA Cancer J Clin 68:394-424. https://doi.org/10.3322/ caac. 21492

2. Saba N, El-Rayes B (2015) Esophageal cancer. Prevention, diagnosis and therapy. Springer, Atlanta. https://doi. org/10.1007/978-3-319-20068-2

3. Abbas G, Krasna M (2017) Overview of esophageal cancer. Ann Cardiothorac Surg 6:131-136. https://doi.org/10.21037/ acs.2017.03.03 
4. Donohoe C, Reynolds J (2017) Neoadjuvant treatment of locally advanced esophageal and junctional cancer: the evidence-base, current key questions and clinical trials. J Thorac Dis S697-S704. https://doi.org/10.21037/jtd.2017.03.159

5. Achilli P, De Martini P, Ceresoli M, Mari GM, Costanzi A, Maggioni D, Pugliese R, Ferrari G (2017) Tumor response evaluation after neoadjuvant chemotherapy in locally advanced gastric adenocarcinoma: a prospective, multi-center cohort study. J Gastrointest Oncol 8:1018-1025. https://doi.org/10.21037/jgo.2017.08.13

6. Godfrey DI, Uldrich AP, McCluskey J, Rossjohn J, Moody DB (2015) The burgeoning family of unconventional T cells. Nat Immunol 16:1114-1123. https://doi.org/10.1038/ni.3298

7. Krijgsman D, Hokland M, Kuppen PJK (2018) The role of natural killer T cells in cancer-a phenotypical and functional approach. Front Immunol 9:367. https://doi.org/10.3389/fimmu.2018.00367

8. Voskoboinik I, Whisstock JC, Trapani JA (2015) Perforin and granzymes: function, dysfunction and human pathology. Nat Revs Immunol 15:388-400. https://doi.org/10.1038/nri3839

9. Giaccone G, Punt CJ, Ando Y, Ruijter R, Nishi N, Peters M, von Blomberg BM, Scheper RJ, van der Vliet HJ, van den Eertwegh AJ, Roelvink M, Beijnen J, Zwierzina H, Pinedo HM (2002) A phase I study of the natural killer T-cell ligand alpha-galactosylceramide (KRN7000) in patients with solid tumors. Clin Cancer Res 8:3702-3709

10. Kunii N, Horiguchi S, Motohashi S, Yamamoto H, Ueno N, Yamamoto S, Sakurai D, Taniguchi M, Nakayama T, Okamoto Y (2009) Combination therapy of in vitro-expanded natural killer $\mathrm{T}$ cells and $\alpha$-galactosylceramide-pulsed antigen-presenting cells in patients with recurrent head and neck carcinoma. Cancer Sci 100:1092-1098. https://doi.org/10.1111/j.1349-7006.2009.01135 .X

11. Motohashi S, Nagato K, Kunii N, Yamamoto H, Yamasaki K, Okita K, Hanaoka H, Shimizu N, Suzuki M, Yoshino I, Taniguchi M, Fujisawa T, Nakayama T (2009) A phase I-II study of $\alpha$-galactosylceramide-pulsed IL-2/GM-CSF-cultured peripheral blood mononuclear cells in patients with advanced and recurrent non-small cell lung cancer. J Immunol 182:2492-2501. https:// doi.org/10.4049/jimmunol.0800126

12. Yamasaki K, Horiguchi S, Kurosaki M, Kunii N, Nagato K, Hanaoka H, Shimizu N, Ueno N, Yamamoto S, Taniguchi M, Motohashi S, Nakayama T, Okamoto Y (2011) Induction of NKT cell-specific immune responses in cancer tissues after NKT celltargeted adoptive immunotherapy. Clin Immunol 138:255-265. https://doi.org/10.1016/j.clim.2010.11.014

13. Exley MA, Friedlander P, Alatrakchi N, Vriend L, Yue SC, Sasada T, Zang W, Mizukami Y, Clark J, Nemer D, LeClair K, Canning C, Daley H, Dranoff G, Giobbie-Hurder A, Hodi FS, Ritz J, Balk SP (2017) Adoptive transfer of invariant NKT cells as immunotherapy for advanced melanoma: a phase 1 clinical trial. Clin Cancer Res 23:3510-3519. https://doi.org/10.1158/1078-0432. CCR-16-0600

14. Szász AM, Lánczky A, Nagy Á, Förster S, Hark K, Green JE, Boussioutas A, Busuttil R, Szabó A, Győrffy B (2016) Cross-validation of survival associated biomarkers in gastric cancer using transcriptomic data of 1,065 patients. Oncotarget 7:49322-49333. https://doi.org/10.18632/oncotarget.10337

15. Dockry E, O'Leary S, Gleeson LE, Lyons J, Keane J, Gray SG, Doherty DG (2018) Epigenetic induction of CD1d expression primes lung cancer cells for killing by invariant natural killer T cells. Oncoimmunology 7:e1428156. https://doi. org/10.1080/2162402X.2018

16. O'Reilly V, Zeng SG, Bricard G, Atzberger A, Hogan AE, Jackson J, Feighery C, Porcelli SA, Doherty DG (2011) Distinct and overlapping effector functions of expanded human $\mathrm{CD}^{+}, \mathrm{CD} 8 \alpha^{+}$and CD4 ${ }^{-} \mathrm{CD} 8 \alpha^{-}$invariant natural killer T cells. PLoS ONE 6:e28648. https://doi.org/10.1371/journal.pone.0028648
17. Ansari AW, Temblay JN, Alyahya SH, Ashton-Rickardt PG (2010) Serine protease inhibitor 6 protects iNKT cells from self-inflicted damage. J Immunol 185:877-883. https://doi. org/10.4049/jimmunol.1000651

18. Kenna T, Golden-Mason L, Porcelli SA, Koezuka Y, Hegarty JE, O'Farrelly C, Doherty DG (2003) NKT cells from normal and tumor-bearing human livers are phenotypically and functionally distinct from murine NKT cells. J Immunol 171:1775-1779

19. Molling JW, Moreno M, van der Vliet HJ, van den Eertwegh AJ, Scheper RJ, von Blomberg BM, Bontkes HJ (2008) Invariant natural killer T cells and immunotherapy of cancer. Clin Immunol 129:182-194. https://doi.org/10.1016/j.clim.2008.07.025

20. Berzins SP, Smyth MJ, Baxter AG (2011) Presumed guilty: natural killer T cell defects and human disease. Nat Rev Immunol 11:131-142. https://doi.org/10.1038/nri2904

21. Ghnewa Y, O'Reilly V, Vandenberghe E, Browne P, McElligott A, Doherty D (2017) Retinoic acid induction of CD1d expression primes chronic lymphocytic leukemia B cells for killing by $\mathrm{CD}^{+}$invariant natural killer T cells. Clin Immunol 183:91-98. https://doi.org/10.1016/j.clim.2017.08.002

22. Hix LM, Shi YH, Brutkiewicz RR, Stein PL, Wang CR, Zhang M (2011) CD1d-expressing breast cancer cells modulate NKT cell-mediated antitumor immunity in a murine model of breast cancer metastasis. PLoS ONE 6:e20702. https://doi. org/10.1371/journal.pone.0020702

23. Miura S, Kawana K, Schust DJ, Fujii T, Yokoyama T, Iwasawa Y, Nagamatsu T, Adachi K, Tomio A, Tomio K, Kojima S, Yasugi T, Kozuma S, Taketani Y (2010) CD1d, a sentinel molecule bridging innate and adaptive immunity, is downregulated by the human papillomavirus (HPV) E5 protein: a possible mechanism for immune evasion by HPV. J Virol 84:11614-11623. https:// doi.org/10.1128/jvi.01053-10

24. Dasari S, Tchounwou PB (2014) Cisplatin in cancer therapy: molecular mechanisms of action. Eur J Pharmacol 740:364-378. https://doi.org/10.1016/j.ejphar.2014.07.025

25. Longley DB, Harkin DP, Johnston PG (2003) 5-fluorouracil: mechanisms of action and clinical strategies. Nat Revs Cancer 3:330-338. https://doi.org/10.1038/nrc1074

26. Horwitz SB (1994) Taxol (paclitaxel): mechanisms of action. Ann Oncol 5(Suppl 6):S3-S6

27. Ohtsukasa S, Okabe S, Yamashita H, Iwai T, Sugihara K (2003) Increased expression of CEA and MHC class I in colorectal cancer cell lines exposed to chemotherapy drugs. J Cancer Res Clin Oncol 129:719-726. https://doi.org/10.1007/s0043 2-003-0492-0

28. Wan S, Pestka S, Jubin RG, Lyu YL, Tsai YC, Liu LF (2012) Chemotherapeutics and radiation stimulate MHC class I expression through elevated interferon- $\beta$ signaling in breast cancer cells. PLoS ONE 7:e32542. https://doi.org/10.1371/journal.pone.00325 42

29. Sewell HF, Halbert CF, Robins RA, Galvin A, Chan S, Blamey RW (1993) Chemotherapy-induced differential changes in lymphocyte subsets and natural-killer-cell function in patients with advanced breast cancer. Int J Cancer 55:735-738

30. Wijayahadi N, Haron MR, Stanslas J, Yusuf Z (2007) Changes in cellular immunity during chemotherapy for primary breast cancer with anthracycline regimens. J Chemother 19:716-723. https:// doi.org/10.1179/joc.2007.19.6.716

31. Markasz L, Stuber G, Vanherberghen B, Flaberg E, Olah E, Carbone E, Eksborg S, Klein E, Skribek H, Szekely L (2007) Effect of frequently used chemotherapeutic drugs on the cytotoxic activity of human natural killer cells. Mol Cancer Ther 6:644-654. https ://doi.org/10.1158/1535-7163.Mct-06-0358

32. Shi L, Lin H, Li G, Sun Y, Shen J, Xu J, Lin C, Yeh S, Cai X, Chang C (2016) Cisplatin enhances NK cells immunotherapy efficacy to suppress HCC progression via altering the androgen 
receptor (AR)-ULBP2 signals. Cancer Letts 373:45-56. https:// doi.org/10.1016/j.canlet.2016.01.017

33. Okita R, Nojima Y, Maeda A, Saisho S, Shimizu K, Nakata M (2016) Repeated exposure to cisplatin enhances NK cell-mediated cytotoxicity via up-regulation of NKG2D ligands in non-small cell lung cancer cells. Ann Oncol 27:1528. https://doi.org/10.1093/ annonc/mdw392.10

34. Zhou WJ, Chang KK, Wu K, Yang HL, Mei J, Xie F, Li DJ, Li MQ (2018) Rapamycin synergizes with cisplatin in antiendometrial cancer activation by improving IL-27-stimulated cytotoxicity of NK cells. Neoplasia 20:69-79. https://doi.org/10.1016/j. neo.2017.11.003

35. Chen J, Huang X, Huang G, Chen Y, Chen L, Song H (2012) Preconditioning chemotherapy with cisplatin enhances the antitumor activity of cytokine-induced killer cells in a murine melanoma model. Cancer Biother Radiopharm 27:210-220. https:// doi.org/10.1089/cbr.2011.1116

36. Fallarini S, Paoletti T, Orsi Battaglini N, Lombardi G (2012) Invariant NKT cells increase drug-induced osteosarcoma cell death. Br J Pharmacol 167:1533-1549. https://doi.org/10.111 $1 / \mathrm{j} .1476-5381.2012 .02108 . x$
37. Ramakrishnan R, Assudani D, Nagaraj S, Hunter T, Cho HI, Antonia S, Altiok S, Celis E, Gabrilovich DI (2010) Chemotherapy enhances tumor cell susceptibility to CTL-mediated killing during cancer immunotherapy in mice. J Clin Invest 120:1111-1124. https://doi.org/10.1172/jci40269

38. Bossard C, Belhadj K, Reyes F, Martin-Garcia N, Berger F, Kummer JA, Briere J, Baglin AC, Cheze S, Bosq J, Ribrag V, Gisselbrecht C, Mounier N, Gaulard P (2007) Expression of the granzyme B inhibitor PI9 predicts outcome in nasal NK/T-cell lymphoma: results of a Western series of 48 patients treated with first-line polychemotherapy within the Groupe d'Etude des Lymphomes de l'Adulte (GELA) trials. Blood 109:2183-2189. https ://doi.org/10.1182/blood-2006-07-033142

Publisher's Note Springer Nature remains neutral with regard to jurisdictional claims in published maps and institutional affiliations. 